\title{
Ach (Ah, Alas)
}

John H. SMith

To cite this article: Smith, John H. "Ach (Ah, Alas)." Goethe-Lexicon of Philosophical Concepts 1, no. 1, 2021: 6-19.

To link to this article: https://doi.org/10.5195/glpc.2021.28

Published by the University Library System, University of Pittsburgh.

\section{(c)}

Entries in this Lexicon are licensed under a Creative Commons Attribution 4.0 United States License.

Copyright @ the Author(s). 


\section{Ach (Ah, Alas)}

The lexeme $A c h$ (ah, alas), though hardly a concept, let alone a traditional philosophical one, plays an important role in Goethe's writing as a means of enacting and performing some of the poet's fundamental conceptual principles. The very mode of this interjection's production in speech - which makes possible the voicing of the almost imperceptible flow of breath through a mild constriction of the throat-embodies Goethe's dialectical understanding of the conjunction of materiality and spirituality (from spiritus, which in Latin means breath). With its prominent use in a number of works in verse (including Faust), where it often serves to initiate or interrupt a line, this common interjection offers a heterodox Goethean reconceptualization of the creative process as an opening and a bridging. It thereby also captures a caesura within being that is comparable to the transitions between inhalation and exhalation.

\section{Introduction}

Ach is an early entry in the Goethe-Wörterbuch, wedged between proper name, "Acerbi," and the place name, "Achaia." There one can find listed the dozens of places where this interjection occurs in Goethe's oeuvre. The entry organizes these occurrences under eight categories that indicate its general rhetorical/expressive or grammatical function, for example:

Ausdruck der Sehnsucht u Klage, der schmerzl Besinnung u der bes. Empfindungsfülle...; als Parenthese...; als Substantiv; Sterbe- und Ohnmachtslaut; Seufzer der Erleichterung; Ausdruck des Einhaltens $u$ Erstaunens, des Erschreckens $u$ der angstvollen Frage; als satzunterbrechende Partikel, die eine negative Wendung im Gedankengang einleitet. ${ }^{1}$

Expression of desire or plaint, of painful reflection or of particularly overwhelming sentiment...; as parenthesis...; as substantive...; uttered sound upon dying or fainting...; sigh of relief...; expression of being taken aback and awe, of terror and anxious questioning; [and, in a formulation that will be important for my approach, JHS] as a part of speech to interrupt a sentence and introduce a negative turn in the flow of thought.

But the question for the purposes of this lexicon is: What kind of philosophical pork is this term doing?
Although it does not have meaning in the sense of a lexical reference, how does it function within Goethe's works to reveal something essential about Goethe's own way of thinking? Like all such interjections, $A c h$ is used to express a wide variety of emotions. However, Ach also captures in the very materiality of its expression, i.e., in the way it gives voice to breathing, what I will refer to as the ontology of the caesura, that which in existence itself separates as it unites and unites as it separates. It marks a break-often a painful one for the speaking subject-in the flow of being, a gap that also opens up a possibility for creativity and renovation. Goethe formulates this dialectical principle explicitly in the "Maximen und Reflexionen" (1833; Maxims and Reflections):

Jedes Existierende ist ein Analogon alles Existierenden; daher erscheint uns das Daseyn immer zu gleicher Zeit gesondert und verknüpft. Folgt man der Analogie zu sehr, so fällt alles identisch zusammen; meidet man sie, so zerstreut sich alles in's Unendliche. In beiden Fällen stagnirt die Betrachtung, einmal als überlebendig, das andere Mal als getötet. (FA 1.13:46) ${ }^{2}$

Every thing that exists is an analogy of everything that exists; thus being appears to us simultaneously as isolated and conjoined. However, if one pursues the analogy too far then everything collapses into an identity; if one avoids it entirely then everything disperses into infinity. In both cases 
reflection stagnates, either as overly stimulated or as annihilated.

And again from Maximen und Reflexionen: "Ist das ganze Daseyn ein ewiges Trennen und Verbinden, so folgt auch, daß die Menschen im Betrachten des ungeheuren Zustandes auch bald trennen, bald verbinden werden" (FA 1.13:48; If being itself is an eternal process of separating and uniting then it follows that humanity, in reflecting on the enormity of this condition, likewise will be engaged alternately in separating and uniting). With the interjection $A c h$ Goethe is able to materialize this aspect of existence in his poetic practice, this balance-or better, pause, painful interruption - between a numbing oneness ("a night in which all cows are black," in Hegel's famous quip from the "Preface" to the Phänomenologie des Geistes [1807; Phenomenology of Spirit]) $)^{3}$ and an infinite dissemination into multiplicity, between fusion and effusion. The very production of the sound, $A c h$, punctuates and bridges the flow of speech, creating rhythm through a caesura of unvoiced inhalation and voiced exhalation.

\section{Ach: From Linguistic Feature to Poetic/ Philosophical Constellation}

The interjection Ach plays many roles in colloquial German, both in the late eighteenth century and today: surprise and wonder, mild reprimand, disappointment, and even despair. Over the course of Goethe's works, one finds all these uses, as indicated in the Goethe-Wörterbuch. But the question remains: is Goethe also thinking through these many and variegated deployments? While Ach may be associated with expressions of feeling, what might we find by exploring the aesthetic and philosophical functions of the interjection? To ask this question is not to deny the expressive character of $A c h$. Rather, it is to give a strong reading of Faust's ebullient outburst: "Gefühl ist alles" (FA 1.7:149.3456; Feeling is everything). Such a reading would not simply reduce everything to feeling, but claim that feeling embraces and, thereby contains, other cognitive acts. Furthermore, while it might seem that in poetry this phoneme can be dismissed as a stressed syllable that simply completes a metric line, why did Goethe rely on it rather than one of the many other single syllable words that could have played the same role? What does this interjection do by punctuating a phrase with a special kind of voiced caesura?
To approach these questions, let us begin at the most material level. The linguistic category, "interjection," comes from the Latin intericere (past participle, interiectus), meaning (physically) to "throw in between." A word like $A c h$ is, so to speak, tossed into a sentence without having an obvious syntactical function. ${ }^{4}$ It has no meaning in the sense of a lexical referent. As an interjection, Ach emphasizes a particular $p h y s-$ ical feature of producing signifiers. Most such interjections are phonemes, sounds that may or may not otherwise appear in the language (so-called primary interjections). They are common in both English and German, and many are similar in their function. The examples are numerous and familiar: 'wow!' (now used also in German) for a kind of surprise filled with wonderment, like Goethe's "Ha!" in Faust (FA 1.7:35.430); 'Bah!' to express dismissal; 'ouch!' or 'aue!' to indicate pain; 'Uh-oh!' or 'Oje!' to indicate concern or regret about an action; and of course many words from other lexical contexts, called secondary interjections, that are used expressively like: 'Damn!'; 'Scheiße!'; 'Heavens!'; 'mein Gott!' One could use these categories to parse Goethe's many Ach's. However, despite the range of emotions expressed by Ach across Goethe's oeuvre, the interjection also importantly enacts central philosophical principles, including the materiality of spirit, the 'polarity and intensification' of life as diastole and systole, as well as its unity and diversity.

How Ach accomplishes its philosophical work is a function of how the body produces it. The process involves two phases: a more or less perceptible inhalation followed by an exhalation (with a slight constriction of the throat) that allows the passing air to create a 'sound' beyond mere breath.

The crucial thing about the bodily production of this sound is that the need to draw in one's breath in preparing the exhalation that produces it also forces a hiatus or caesura. That Goethe had a keen sense of the importance of breathing in the reading of poems can be seen in his "Regeln für Schauspieler" (1803; Rules for actors): "Hat man Iamben zu deklamieren, so ist zu bemerken, daß man jeden Anfang eines Verses durch ein kleines, kaum merkbares Innehalten bezeichnet; doch muß der Gang der Deklamation dadurch

Voiced Breath in Yoga Practice Yogis encourage such minor constriction in order to produce Ujjayi Pranayama, sometimes referred to as "ocean breath," to create awareness of one's breathing and to allow for heightened attentiveness to the rhythms of one's practice. 
Ach as Opening Word There are many poems that open with Ach or contain stanzas with Ach as their first word. The Frankfurt edition of Goethe's poems between 1756 and 1799 lists in the index twenty-two whose first line or title begin with Ach. For example: "Ach wie sehn ich mich nach Dir" (FA 1.1:135; Ach how I long for you): three Ach's; "Menschengefühl" (1776; Human Feeling): "Ach ihr Götter, große Götter" (FA 1.1:206; Ach you gods, great gods); "Beherzigung" (1777, Take heart): "Ach was soll der Mensch verlangen?" (FA 1.1:285; Ach what should one desire); "Alexis und Dora" (1796; Alexis and Dora): "Ach! unaufhaltsam strebet das Schiff..." (FA 1.1:616; Ach! unstoppable surges the ship...). These initiating Ach's signal the sound of creation, as well as the transition of the unformed, inspiring idea, understood as the poet's spirit and breath, and its outpouring into the reality that is the poem itself. See likewise the poems from letters to Frau von Stein: "Ach, so drückt mein Schicksal mich..." (1776; Ach, how my fate presses down upon me...; FA 1.1:232); and the second poem (1776):

Ach, wie bist du mir,
Wie bin ich dir geblieben!
Nein, an der Wahrheit
Verzweifl'ich nicht mehr.
Ach, wenn du da bist,
Fühl ich, ich soll dich nicht lieben,
Ach, wenn du fern bist
Fühl ich, ich lieb' dich so sehr. (FA 1.1:232

Ach, how you remain (steady) to me, and I to you. No, I no longer doubt the truth. Ach, when you are there I feel I ought not love you. Ach, when you are far, I feel I love you so very much.

Time and again Ach marks, instantiates, and initiates a difference as part of a larger process of creative overcoming. The "erhabne[] Schöpfungslust" (sublime creative desire of the divine) is discussed below in relation to Ach in "Wiederfinden" (1813; Re-Encounter; FA 1.2:490) as a kind of ontological principle.

nicht gestört werden" (FA 1.18:870; In declaiming iambic meter it is noteworthy that one needs to mark the beginning of each line of verse by a small, hardly perceptible pause; and yet the flow of the declamation must not be disturbed). Precisely this "hardly perceptible pause" ("kaum merkbares Innehalten") in the middle of a flowing "course" ("Gang") captures the nature of the caesura of the $A c h$-even at the opening of a line. ${ }^{5}$ For the experiencing subject, this brief opening can be a point of breakdown and transformation, crisis and inspiration, rupture and innovation.

At this point, we are ready to consider a first significant constellation of concepts in Goethe's thought-world that makes Ach something more than just a relatively meaningless interjection: it exemplifies the fundamental duality of all life processes and their systolic and diastolic rhythms. Like a heart withdrawing blood in and pumping blood out, the inhalation and exhalation of the lungs forming the Ach marks and performs the fundamental rhythmic flow of being, the interplay between the oneness of flow and the moments of pause ("Innehalten") between infinitesimal transitions. It thus also ex-presses the moment of transformative potentiality that disrupts and constitutes the rhythmic flow of being. We can turn to another of Goethe's Maximen und Reflexionen for his characterization of this general principle:

Die große Schwierigkeit bei psychologischen Reflexionen ist, daß man immer das Innere und Äußere parallel oder vielmehr verflochten betrachten muß. Es ist immerfort Systole und Diastole, Einatmen und Ausatmen des lebendigen Wesens; kann man es auch nicht aussprechen, so beobachte man es genau und merke darauf. (FA 1.13:367; emphasis in original)

The major difficulty with psychological reflections comes from the fact that one must always consider interiority and exteriority as parallel or even as intertwined with one another. It is always a question of systole and diastole, inhalation and exhalation of living being; even if it cannot be given linguistic expression one must observe it and attend to it carefully. 
Benedetto Croce on Fundamental Intuitions To appreciate the radical function of this interjection - which is not a traditional philosophical concept but poetically enacts what cannot be fully captured in them-we might consider a passage from Benedetto Croce's Aesthetic as Science of Expression and General Linguistic (1902), in which he argues that space and time are not, as in Kant, the most fundamental forms of intuition: "We have intuitions without space and without time: the colour of a sky, the colour of a feeling, a cry of pain..." ("ein Ach des Schmerzes" in the German translation). 'Such intuitions make up what Croce calls the "character, individual physiognomy" of art (Croce, Aesthetic, 5). For Goethe, too, Ach works like a kind of transcendental form of intuition, a condition of possibility for both the separation of individuated entities and their reunification.

i. Benedetto Croce, Aesthetic as Science of Expression and General Linguistic, translated by Doublas Ainslie (London, Macmillan and Co., 1922), 4; Croce, Aesthetik als Wissenschaft des Ausdrucks und allgemeine Linguistik, translated by Karl Federn (Leipzig: E. A. Seemann, 1905), 4.

Using the components of linguistic productionbreath, constriction of the throat-the Ach expresses indirectly what is otherwise inexpressible in language. It allows us to attend to an underlying principle at work in the activity of living nature as such, an activity that brings with it moments of suffering - "aching"-on the way to a new being. Become observant of the Ach and you will hear the almost imperceptible interval between internalizing and externalizing motions of existencethat material caesura of the breath that separates and joins the rhythmic flow.

\section{Faust's Ach's}

The significant philosophical role of Ach in Goethe's writing was noted by Friedrich Kittler at the beginning of his pathbreaking Aufschreibesysteme 1800/1900 (1995; Discourse Networks 1800/1900). Before citing the opening lines of Faust, Kittler observes: "Die deutsche Dichtung hebt an mit einem Seufzer" (German literature commences with a sigh). ${ }^{6}$ Kittler is certainly right to start where he does. That these three letters stand out is clear, especially to whomever first encounters Goethe's thought through his most famous and influential drama, where, as the third 'word' in the protagonist's opening monologue, Ach has the pride of place: "Habe nun, ach! Philosophie..." (FA 1.7:33.354)—or in the first version, Urfaust: "Hab nun ach die Philosophey" (FA 1.7:469.1). The opening of the play is an opening within Faust, an interjection marking a rejection born of despair.

The interjection, according to Kittler, might appear to be serving a linguistic function by marking straight off in this foundational text of modern literature an expres- sion of subjectivity. And yet, he continues, by coming to expression in language this subjective moment is already displaced by it. In a particular way, we could say with a Derridean inflection, the $A c h$ marks the presence of an absence (of the subject). Kittler expounds his point with a reference to an epigram, one of the so-called Xenien written during the fruitful period of German Classicism by Goethe's close friend Friedrich Schiller:

Hervorbringt den Seufzer kein namenloses Iches kommt im Satz nicht vor-, erst recht also kein namhafter Autor. Was den Tonfall altdeutscher Knittelverse durchkreuzt, ist eine reine Seele. Verse des anderen Klassikers [Schiller] bestätigen es: Der Seufzer ach ist das Zeichen jener einmaligen Wesenheit, die, wenn sie irgendeinen anderen Signifikanten oder, da es Signifikanten nur im Plural gibt, Signifikanten überhaupt in den Mund nähme,

How Faust Begins with an Ach Granted, the scene "Nacht (Night)" is not the first scene in the final published version, which opens with the dedicatory poem, "Zueignung" (Dedication) and the prefatory "Vorspiel auf dem Theater" (Prelude at the Theater) and "Prolog im Himmel" (Prologue in Heaven), all written in the late 1790s; but when Goethe sat down in the early 1770s to begin work on the play, "ach" would, in fact, have been the third word he wrote. But even in the later versions, Ach appears early, in the third strophe of the opening dedicatory poem: "Zerstoben ist das freundliche Gedränge / Verklungen ach! der erste Widerklang" (FA 1.7:11.19-20; the friendly crowd is dispersed, silent, ach!, the first echoing sounds). 
gleich wieder zu ihrem einen Seufzer zurückkehren müßte; denn schon wäre sie nicht mehr Seele, sondern (der Titel ist unzweideutig) Sprache.

"Warum kann der lebe dige Geist dem Geist nicht erscheinen? Spricht die Seele, so spricht, ach! schon die Seele nicht mehr." (Kittler, Aufschreibesysteme, 11)

It is no nameless $I$ that brings forth the sigh-indeed, there is no $I$ in the sentence-and certainly not a named author. What intersects the inflection of the traditional German meter (Knittelvers) is a pure soul. This is confirmed in the lines by the other Classicist [Schiller]: The sigh ach is the sign of that unique entity that, once it takes a signifier (or rather, signfiers, since they only exist in the plural) into its mouth, must retreat back into its sigh. For at that point, as the title of the epigram makes clear, this entity is no longer a soul but language itself:

"Why cannot the living spirit appear to itself as spirit? Once the soul itself speaks, ach!, no longer is it a soul." (my translation; emphasis in original)

One does not need to subscribe to Kittler's particular conception of the desubjectifying force of language in order to recognize a powerful insight here that can be modified and generalized: this aspirated sigh captures in the materiality of sound Goethe's version of dialectical thinking that places opposites - presence/absence, separation/unity, diastole/systole, polarity/intensificationwithin a breath's distance of each other.

Beyond this famous first line, Ach punctuates some of the most important and memorable lines of the play.
Early in the opening "Night" scene, Faust, despite his stated disdain for bookish learning, seizes the tome of Nostradamus. He observes the Sign of the Macrocosm and is bedazzled by the interplay of the lineaments. But he turns on a dime, crying out: "Welch Schauspiel! aber ach! ein Schauspiel nur!" (FA 1.7:36.454; What a spectacle [or play]! But ach! only a spectacle [or play]!). We have here an instance of what the Goethe-Wörterbuch terms "a part of speech to interrupt a sentence and introduce a negative turn in the flow of thought." In separating the two exclamations of the same word, Ach performs the differentiating act that inheres within the iteration of identity. Were it not for the internal difference that nonetheless binds the repeated word Schauspiel into a cohesive verse, the repetition would collapse into the kind of identity that we saw Goethe dismiss in his maxim above. The caesura here separates the two kinds of effects that a play-both metaphorically and literally-can produce. On the one hand it can raise the viewer to new heights, while on the other, it can be empty appearance (a Platonic imitation of an imitation). That is to say, Faust recognizes that the apparent fullness of representation contains the void out of which it emerges. However, in distinguishing these two kinds of Schauspiel, the aber ach! reminds us that in the instance of the utterance both kinds of Schauspiel are conjoined by the very play that is appearing before the theatrical spectator's eyes. One is reminded of Hegel's crucial line in the "Introduction" to the Phenomenology of Spirit, introduced by what Heidegger called "the decisive 'but'" (das entscheidende 'Aber'). ${ }^{7}$ According to Hegel, one should not assume that the validity of a new philosophy will relegate all other philosophies to false appearances: "Aber die Wissenschaft darin, daß sie auftritt, ist sie selbst eine Erscheinung [...] Die Wissenschaft muß sich aber von diesem Scheine befreien,

Caesura in the Classical Distich The fact that Schiller places the Ach in the center of the pentameter, where classical prosody would require a caesura formed by the juxtaposition of a spondee's two stressed syllables, reveals a deeper poetic principle at work. Its presence at the beginning of Faust demonstrates that Goethe was aware of this metrical practice even before he mastered the art of the distich, with its strong caesura in the middle of the pentameter. If Urfaust/Faust begins with a caesura, it is following in the footsteps of Homer's lliad, even if the translation does not capture the caesura caused

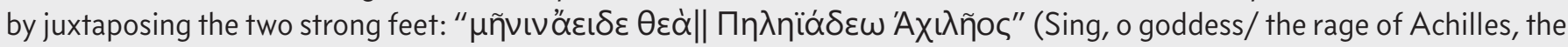
son of Peleus). See also Virgil's Aenead: "Arma virumque cano/ Troiae qui primus ab oris" (Of arms and the man, I sing/ Who first from the shores of Troy). 
On Double-Consciousness W.E.B. Du Bois derived his famous concept of "double-consciousness" from this line of Faust. He had seen the play during his sojourn in Berlin (1892-94). As he writes in The Souls of Black Folk (1903): "One ever feels his twoness - an American, a Negro; two souls, two thoughts, two unreconciled strivings; two warring ideals in one dark body."i In Goethe's Faust, this twoness is caused and bridged by the Ach.

i. W.E.B. Du Bois, The Souls of Black Folk, in: Writings, ed. Nathan Huggins (New York: Library of America, 1986), 364-65.

und sie kann dies nur dadurch, daß sie sich gegen ihn wendet" (Hegel, Phenomenology of Spirit, §76; But scientific knowledge, in appearing on stage, is itself an appearance [...] Scientific knowledge must free itself from this mere appearance, and it can do so only by turning itself against it). In both cases, the 'truth' of the play/appearance can only emerge by allowing the appearance to appear in an act of immanent negation.

In a somewhat different sense, $A c h$ enacts the internal division within a single consciousness when Faust confesses to Wagner: "Zwei Seelen wohnen, ach! in meiner Brust" (FA 1.7:57.1112; Two souls abide, ach! in my breast). The countermovement of the souls - one would fly up in aspiration, while the other would cling to the earth - matches the pause introduced into this line by the inhalation/exhalation that produces the materialized breath-spirit of the Ach. In this case one might be tempted to dismiss the interjection as a mere means to fill out the iambic meter of the line. But one needs only imagine how differently the line would work, if Goethe had supplied some monosyllabic word, say, 'tief' (deep) or 'stets' ('always,' 'ever'). In both of these cases the flow continues uninterrupted from the beginning to the end of the line. By using ach, however, Goethe forces an ever-so-slight pause in order to inhale briefly for the exclamation's exhale. Within that moment, the principle of "double-consciousness" becomes realized in the poetry.

When Faust returns to his study in the immediately following scene, the existing tension that will drive the plot forward to the pact (or bet) with the devil further unfolds both humorously and around a couple of Ach's. Having brought the devilish poodle into his home, Faust's claim to have found a new inner peace ("Entschlafen sind nun wilde Triebe, / Mit jedem ungestümen Tun; / Es reget sich die Menschenliebe, / Die Liebe Gottes regt sich nun [FA 1.7:60.11821185; Our wilder impulses are stilled, / And all our hasty actions, when / The peaceful heart with love is filled / For God and for our fellow men]) is interrupted twice by the growling dog ("Sei ruhig, Pudel! [FA 1.7:60.1186; Be quiet, poodle!]; "Knurre nicht, Pudel!" [FA 1.7:60.1202; Poodle, stop growling!). ${ }^{8}$ And those discordant notes - the canine response to Faust's high sentiments - are followed by parallel stanzas that are both introduced with the $A c h$ :

Ach wenn in unsrer engen Zelle

Die Lampe freundlich wieder brennt,

Dann wird's in unserm Busen helle,

Im Herzen, das sich selber kennt.

Vernunft fängt wieder an zu sprechen,

Und Hoffnung wieder an zu blühn;

Man sehnt sich nach des Lebens Bächen,

Ach! nach des Lebens Quelle hin.

(FA 1.7:60.1194-97)

(Ach) When the friendly lamp burns bright

Confined within this narrow cell,

The heart that knows itself aright

Can find enlightenment as well.

Then hope once more within us swells,

And reason speaks again, it seems;

We long to seek the deepest wells

$(A c h)$ of life, and drink from living streams.

These sighs instantiate the inner disturbance at the heart of Faust's subjectivity. After the second interruption by the poodle/Mephistopheles, he marks his existential crisis with an Ach: "Aber ach! schon fühl' ich, bei dem besten Willen, / Befriedigung nicht mehr aus dem Busen quillen" (FA 1.7:60.1210-11; But [Ach!] though my spirit wills it, still I cannot find / That true contentment and serenity of mind). If, as Kittler has argued, with the translation scene we have the simultaneous emergence and linguistic occlusion of a lyrical self, the punctuation by Ach marks Goethe's philosophical appreciation of this discordant rhythm. 
Gretchen's Ach's The fact that Gretchen utters Ach at least as often as Faust opens up her character to important interpretive work. A few notable examples must suffice. As she contemplates herself in the mirror with the jewelry bestowed on her by Faust and Mephistopheles, she captures her ambivalent position turning on the Ach: "Nach Golde drängt / Am Golde hängt / Doch Alles. Ach wir Armen!" (FA 1.7:89.2802-04; Everyone wants gold, it's all about the gold, ach our poverty). In her song at the spinning wheel, as she lists Faust's features, the Ach marks the turn to her desire: "Und seiner Rede / Zauberfluß, / Sein Händedruck, / Und ach sein Kuß!" (FA 1.7:146.3398-401; And the magic of his speech, the touch of his hand, and ach his kiss). And in the scene at the well, when her friend Lieschen badmouths another girl for being pregnant out of wedlock ("she's eating for two"), Gretchen expresses her own impossible position with a one-word line, the shortest in the play: "Ach!" (FA 1.7:154.3550). Indeed, Ach occurs two more times in the next forty lines, literally spanning the end of this scene and the opening of the next (FA 1.7:154-56.3556-87). A final example comes at the moment of her recognition of Faust's contradictory nature in the prison scene, turning (as noted in the Goethe-Wörterbuch) into its opposite around the axis of the Ach: "Deine liebe Hand! - Ach, aber sie ist feucht" (FA 1.7:196.4512; Your dear hand! - Ach, but it is damp [with blood]), which she follows up with: "Ach Gott! Was hast du getan?" (FA 1.7:196.4515; Ach God, what have you done?). At first, one might be tempted to see these utterances as purely expressive of her inner emotional state. Such a reading would be in line with gendered approaches, aligning Faust with the "ideas" and Gretchen with "feeling." However, in her case, too, we need to see that the Ach indicates the ways in which she must grapple with the experience of a duality that has arisen in her identity. The Ach in Gretchen signifies the collapse of her world and order that she recognizes even as she is in love with the source of her (heart)ache.

\section{Ach and the Ontology of the Caesura: "Wiederfinden"}

Goethe raises the textual praxis of the spoken caesura - which the versified $A c h$ expresses as a separating and uniting-to an ontological principle. That is, the apparently non-philosophical interjection becomes a strange object of significant reflection. We can find this principle explicitly stated in two significant poems from the West-östlicher Divan (1819; WestEast Divan). Thus, in one of the "Talismane" poems from the beginning of the collection, which serve as a guide for the entire cycle, breathing constitutes the fundamental feature of life and connects the human and divine realms:

Im Athemholen sind zweyerley Gnaden:

Die Luft einziehn, sich ihrer entladen.

Jenes bedrängt, dieses erfrischt;

So wunderbar ist das Leben gemischt.

Du danke Gott, wenn er dich preßt,

Und dank' ihm, wenn er dich wieder entläßt.

(FA 1.3:15)

Breathing provides two kinds of gifts: drawing in fresh air and releasing it again. We are beset by the latter, refreshed by the former. In this way life is wonderfully involved. You, thank God when he tries you [puts you under pressure], and thank him when he releases you again.
By making the process of inhalation and exhalation a "gift" of God akin to grace, the finite world of modifications becomes a reflection of the infinite. Goethe furthermore indirectly connects his thinking to the long theological tradition - still very much alive (even if in transition) during his own time - that emphasized the materiality of breath within the spiritual, as the root words spiro and pneuma suggest.

The principle of breathing as dual process that connects the human and divine is explicitly related to the Ach near the beginning of the poem "Wiederfinden" from the "Buch Suleika" in the West-östlicher Divan. There Goethe makes the interjection a substantive to designate a primal metaphysical event. In the first stanza the interjection is used conventionally to voice the subjective pain and sadness of separation from the beloved: "Ach! was ist die Nacht der Ferne / Für ein Abgrund, für ein Schmerz" (FA 1.3:96; Ach! what is a night far from you, but an abyss and a torment). As in Suleika's response in "Nachklang" (FA 1.3:95; "Echo") or Hatem's playful exchange over her new poems (FA 1.3:91), the Ach here once again makes possible the trochaic meter, with its emphasis on the first syllable of the line. Additionally, it also marks the depths of a separation: the breath introduced before "was ist die Nacht der Ferne" actualizes the distancing and pause (what Goethe termed an "Innehalten" while declaiming) within the spoken line itself.

In the second stanza the poem then quickly opens onto a cosmic perspective, tracing this separation back to the originary act of creation. Here we can detect a movement that is 
akin to the movement in the maxim cited above, namely, the possibility of a kind of infinite dissemination and scattering ("so zerstreut sich alles ins Unendliche"). Goethe captures in a few lines how, "mit erhabner Schöpfungslust" (with sublime creative pleasure) and with the flash of a divine big bang, the world moved from a state of absolute unity "an Gottes ew'ger Brust" (FA 1.3:96; at God's eternal breast) to its own becoming: "Und er sprach das Wort: Es werde!" (FA 1.3:96; And he spoke the word: Let it become [come into being]!) And at this point, with the first linguistic expression bringing forth being, the universe resounds, not with some joyful expression associated with God's creative act, but rather with its own exhaled and painful interjection:

Da erklang ein schmerzlich Ach!

Als das All, mit Machtgebärde,

In die Wirklichkeiten brach. (FA 1.3:96

There resounded a painful $A c h$ ! when, with this powerful gesture, the universe splintered into realities [the plentitude of beings].

If Faust struggled to find the appropriate word to translate the beginning as logos, the lyrical voice of "Wiederfinden" plays with the powerful phoneme $a-c-h$ to capture the explosive act of distancing that brings forth materiality as such out of the spirit of creation. In Faust as well as in the lyric poetry, that is, Ach - as both sight and sound - materializes the subject's reckoning with the ontological $U r$-Ach of creation and its painful rupture. With its transformation of the interjection into a substantive, the poem marks it as both sound and ontological principle. ${ }^{9}$ Being itself unfolds here not-as in Faust's translation of the divine logos - as "word," "meaning," "force," or "deed" (Wort, Sinn, Kraft, or Tat), but out of a sheer expulsion of breath that produces the universe with a painful cut in the divine. The individuation of things emerges with the caesura formed by the pained voiced expiration. Ach thus comes to mean the introduction of difference into being, which is a principle that Goethe would have known well from Spinoza: "Omnes determinatio est negatio" (All determination/particularization is negation). In order for there to be a world of individuated, determinate things (Dasein), the primal unity needs to be shattered and the limit defining each finite thing negatively vis-à-vis every other such thing needs to be established. Accordingly, the first ontological Ach! appears with the unfolding of the All into the myriad and particular realities on the breath of the divine as a primal diastolic moment-from Greek dia (meaning apart) and stellein (to place).With the emergence of light, the poem continues, darkness likewise arose as it flees its opposite; the elements disperse and space itself opens up:
Auf tat sich das Licht! So trennte
Scheu die Finsterniß von ihm, Und sogleich die Elemente
Scheidend auseinander fliehn.
Rasch, in wilden wüsten Träumen,
Jedes nach der Weite rang,
Starr, in ungemeßnen Räumen,
Ohne Sehnsucht, ohne Klang. (FA 1.3:97)

The Scientific Writings In fact, Goethe himself draws interesting parallels between color and breath, sight and sound, in the "Foreword" (Vorwort) to the "Didactic Part" of his Farbenlehre (1808; Theory of Color). The second paragraph states a basic philosophical principle, namely, it is impossible to grasp the essence of any thing, since we can only know its effects; indeed, the essence would only be the full (hi)story of its effects: "Denn eigentlich unternehmen wir umsonst, das Wesen eines Dinges auszudrücken. Wirkungen werden wir gewahr und eine vollständige Geschichte dieser Wirkungen umfaßte wohl allenfalls das Wesen jenes Dinges" (FA 1.23:12; We attempt in vain to express the essence of a thing. We perceive only effects and a complete history/story of these effects would at best encompass the essence of each thing). Thus, one can know something about light only through colors, "Taten und Leiden" ("the deeds and passive effects") of light. Further, color and light are themselves only a part of the network of effects through which we understand creative nature itself through the sense of sight. But then he points also to the wonders of the sense of hearing:

Ebenso entdeckt sich die ganze Natur einem anderen Sinne. Man schließe das Auge, man öffne, man schärfe das Ohr, und vom leisesten Hauch bis zum wildesten Geräusch, vom einfachsten Klang bis zur höchsten Zusammenstimmung, von dem heftigsten leidenschaftlichen Schrei bis zum sanftesten Worte der Vernunft ist es nur die Natur, die spricht, ihr Dasein, ihre Kraft, ihr Leben und ihre Verhältnisse offenbart, so daß ein Blinder, dem das unendlich Sichtbare versagt ist, im Hörbaren ein unendlich Lebendiges fassen kann. (FA 1.23:12) 
In a similar way all of nature reveals itself to another of the senses. In closing one's eyes, one opens and sharpens the ear and from the slightest breath to the wildest din, from the simplest tone to the highest harmonies, from the most violent and passionate cry to the gentlest words of reason -in all this it is only nature speaking, revealing her being, force, life, and interrelations. Thus, one who is blind, to whom is denied the infinity of the visible, can nonetheless grasp in the audible the infinity of life.

My argument here is that the inarticulate sound of Ach, produced by the mere constriction of the throat while exhaling, serves as an audible product of a principle of nature itself and introduces into language a binding caesura that works much like natural processes.

Further, in his treatise on weather, Versuch einer Witterungslehre (1826; Essay on meteorology), Goethe reintroduces the idea that color is the effect of light and darkness on a material medium in analogy ("Analogie") to the way the forces of attraction ("Anziehungskraft") and expansive warming ("Erwärmungskraft") produce weather conditions thanks to the "fine materiality of air" (FA 1.25:311; die feine Luft-Materialität). At the end of the Farbenlehre, he reformulates this analogical principle by emphasizing that all phenomena,

alles, was erscheinen, was uns als ein Phänomen begegnen solle, müsse entweder eine ursprüngliche Entzweiung, die einer Vereinigung fähig ist, oder eine ursprüngliche Einheit, die zur Entzweiung gelangen könne, andeuten und sich auf eine solche Wesise darstellen. Das Geeinte zu entzweien, das Entzweite zu einigen, ist das Leben der Natur; dies ist die ewige Systole und Dastole, die ewige Synkrisis und Diakrisis, das Ein-und Ausatmen der Welt, in der wir leben, weben und sind. (FA 1.25:488)

everything that appears, that we encounter as a phenomenon, must indicate and present itself in one of two ways: either an originary dualism that is capable of a union, or an originary union that can yield a dualism. The life of nature is to divide the united, to unite the divided; this is the eternal systole and diastole, the eternal syncresis and diacrisis, the inhalation and exhalation of the world in which we live and weave our existence.

When Goethe deploys the Ach as a poetic phenomenon, he represents and performs this principle.

And light appeared! Thus, shyly, darkness separated itself from it, and at once the elements fled apart from each other. Rapidly, in wild and crazy dreams, each thing pressed into distance, stiff, in immeasurable spaces, without longing, without a sound.

In the $A c h$, the creative hiatus exists cosmically as well as poetically.

Of course, from the title of the poem one can surmise the wider logic of its narration and the form of Goethe's own thought: In his new isolation ("Einsam Gott zum erstenmal;" FA 1.3:97; God, lonely for the first time), having separated light and darkness, God also created new possibilities of reunion, as in the synaesthetic "erklingend Farbenspiel" (FA 1.3:98; resounding play of colors). Here we have an echo of Goethe's theory of colors, according to which chromatic generation is effected by the play of light and darkness in a "turbid" (trüben) medium. In the terms Goethe borrowed from organic life, the diastolic is always part of a larger process that also involves a systolic component. What was exhaled by God the Creator was also drawn, or propulsed, back into a state gathered into itself. A higher unity could be made: "Und nun konnte wieder lieben / Was erst auseinander fiel" (FA 1.3:98; And now what had fallen apart could again find love.) (In Derridean terms, the primal Ach is the act of différance that opens up and makes differences possible, a pre- or non-temporal deferring, the "in-between" that makes and bridges spatial and temporal differences.) For Goethe, this caesura within being is at the same time the condition of possibility of a reunion within the cosmological rhythm of life. Like the "farbige Abglanz" (colorful reflection) of the sunlight shining off the waterfall in the opening scene of Faust II, Ach is part of a non-conceptual poeisis that effectively produces a heterodox ontology of the Goethean concept, if only indirectly. ${ }^{10}$

\section{Ach in the Lyric Poems}

While Ach appears throughout his oeuvre, the unique demands of rhythm in lyric poetry allow Goethe to deploy this interjection in ways that enact the core principles of his thinking. And from the deeper function of this explo- 
sion of breath, we can understand Goethe's tendency to place $A c h$ in the middle of a line or thought: it unites as it separates and separates as it unites. We can see how this poetic and philosophical principle plays out in four of Goethe's major early poems. It is important to note that Goethe's poetic practice - as in the early versions of Faust-deploys Ach to do a certain kind of philosophical work, even if the poet did not yet have an explicitly formulated position or vocabulary beyond his broadly Spinozistic conception of natura naturans.

In the great hymn, "Mahomets-Gesang" (1773; The Song of Mohammed), this work happens as the "father ocean" opens up his arms to receive the flowing rivers, but they must first await the strength of the prophet to carry them forward:

\section{Bruder!}

Bruder, nimm die Brüder mit!

Mit zu deinem Alten Vater,

$\mathrm{Zu}$ dem ewgen Ozean

Der mit weitverbreiten Armen

Unsrer wartet

Die sich ach vergebens öffnen

Seine Sehnenden zu fassen. (FA 1.1:194)

Brother, / Brother, take your fellow brothers / to your aged father, / to the eternal ocean,/ who with open arms / awaits us; / yet they open, ach, / in vain to grasp us / who long for him.

The Ach occurs just after the midpoint of the poem, which describes the force of a poetically inspired religious genius with the extended metaphor of a river's journey from its mountain sources through the plains and desert to the ocean. The interjection here subtly introduces a pause into the inevitable flow of the water that suggests an existential interruption. For what would happen if the course of the "brother tributaries" were indeed blocked by "a desolate desert" (öde Wüste), "greedy/thirsty sand" (gier'ger Sand), "the sun on high" ( die Sonne droben), or "a hillside" (ein Hügel), thereby preventing the longed for unification and oneness with the "father"? But this brief caesura also opens up the possibility for an even stronger urge toward unity:

Bruder!

Nimm die Brüder von der Ebne

Nimm die Brüder von Gebürgen

Mit, zu deinem Vater mit. (FA 1.1:194)

Brother, / take the brothers from the plains, / take the brothers from the mountains, / to your father!

The $A c h$ becomes the vanishing point in the poem where the hesitation of the inhale, the pause in the metaphorical and literal flowing, established the condition of possibility for the explosive outpouring that follows.

If the poem "Ganymed" unfolds Goethe's early Spinozist views of language, humanity, and nature as united in a living process, then we would expect $A c h$ to have a central place there, not just as an emotive expression but also as an enactment of the process itself. ${ }^{11}$ Like so many of Goethe's other early poems, it traces a dual movement between active and passive states within the lyrical subject that later in Goethe's thinking emerges as the concepts of systolic inhalation (Einatmen) and diastolic exhalation (Ausatmen). Beginning with Nature pressing itself upon the lyrical I, followed by a longing for an active embrace- " $\mathrm{Daß}$ ich dich fassen möcht / In diesen Arm!" (FA 1.1:205; That I might grasp you in this arm) - the poem hinges on two lines with interjections. They capture the heartbeat of the duality and ambiguity at the core of the Ganymedean experience. In the first line, the Ach interrupts the flow as the speaker both hungers (passive, self-loss) and desires (active): "Ach an deinem Busen / Lieg ich, schmachte [...]" (FA 1.1:205; Ach, at your breast / I lie, longing/languishing [...]). Not only does the verb schmachten suggest multiple meanings, but it literally, linguistically, and hence aurally contains the $A c h$ that opens the verse.

And in the second line, we again have Ach playing the role of a caesura, in this case by separating a repeated word: "Ich komme! Ich komme! / Wohin? Ach wohin?" (FA 1.1:205; I'm coming, I'm coming! / Whither, Ach, whither?). Wedged between the two interrogatives, this

A Hidden Ach in "Prometheus"? Since "Ganymed" is often regarded as a pendant to "Prometheus," with both together performing a movement of self-loss and self-promotion ("Entselbstigung" and "Verselbstung"), it is interesting to note the last lines of "Prometheus," where he says of the new race of human beings: "Und dein nicht zu achten / Wie ich!" (FA 1.1:204; And [who will] not worship you / like me!). The "ACHten" is a violent moment of rejection in the generation of a new self. 
Ach expresses the distance within the movement toward a goal and the union being made possible by that movement. Now not just a repetition of the same, the line introduces a moment of difference, an iteration of the non-same, that opens the self up to a higher state and self-loss at the same time, ultimately captured in the famous line: "Umfangend umfangen" (FA 1.1:205; embracing embraced), a purely ambivalent phrase that similarly separates and unites opposites by pivoting around the central " $\mathrm{d}$."

"Wanderers Nachtlied" (1776; The Wanderer's Evening Song"), one of Goethe's most famous, is a short poem of just 41 words. Placed as the 21st, that is, precisely at the center of the poem, the $A c h$ forms the linchpin that bridges two symmetrical halves of the poem even as it also emphasizes a radical grammatical and conceptual break. After the first lines address the "Du" in an echo of the Lord's Prayer, the $A c h$ opens up the turn to the I (Ich) speaking the poem. I can quote the short poem in its entirety:

Der du von dem Himmel bist

Alle Freud und Schmerzen stillest,

Den der doppelt elend ist

Doppelt mit Erquickung füllest,
Ach ich bin des Treibens müde!

Was soll all der Qual und Lust.

Süßer Friede,

Komm ach komm in meine Brust! (FA 1.1:229)

You who are of heaven, who stills all pain and suffering, who doubly revives one suffering doubly. Ach, I am tired of ever pressing on, what's the point of all the pain and pleasure. Sweet peacefulness, come, ach come into my breast.

If in Kittler's reading of Faust the subject of German literature emerges with a "sigh" (Seufzer), here, too, a transition takes place around the interjection, $A c h$, that adopts the religious function of poetry-as-prayer and transforms it into the scene of subjective experience. As in "Ganymed," the final line uses the Ach as a subtle means to vary the repeated "komm" and, thereby, to capture both the active, imperative mood, but also a passive acceptance. The Ach opens up the space within and for the lyrical I. ${ }^{12}$

Another way Ach is deployed can be found the later poem "Dauer im Wechsel" (1803; Permanence in Change), which features the simultaneity of change and

Hegelian Logic avant la lettre Here Goethe captures an idea through a poetic practice that Hegel would formulate philosophically some nine years later in the Wissenschaft der Logik (1812; Science of Logic). He writes of the dialectical nature of infinitesimals:

Diese Größen sind also solche bestimmt worden, die in ihrem Verschwinden sind-nicht vor ihrem Verschwinden, denn alsdann sind sie endliche Größen, - nicht nach ihrem Verschwinden, denn alsdann sind sie nichts. Gegen diesen reinen Begriff is† eingewendet und immer wiederholt worden, daß solche Größen entweder Etwas seien oder Nichts; daß es keinen Mittelzustand (Zustand ist hier ein unpassender, barbarischer Ausdruck) zwischen Sein und Nichtsein gebe. - Es ist hierbei gleichfalls die absolute Trennung des Seins und Nichts angenommen. Dagegen ist aber gezeigt worden, daß Sein und Nichts in der Tat dasselbe sind oder, um in jener Sprache zu sprechen, daß es gar nichts gibt, das nicht ein Mittelzustand zwischen Sein und Nichts ist. Die Mathematik hat ihre glänzendsten Erfolge der Annahme jener Bestimmung, welcher der Verstand widerspricht, zu danken.'

These magnitudes are so determined that they are in their vanishing - not before this vanishing, for they would then be finite magnitudes; not after it, for then they would be nothing. Against this pure thought, it is objected and endlessly repeated that these magnitudes are either something or nothing; that there is no intermediary state between being and nothing ("state" is here an inappropriate barbaric expression). - Assumed here is again the absolute separation of being and nothing. But we have shown against this that being and nothing are in fact the same, or to speak in the language cited, that there is nothing which is not an intermediary state between being and nothing. Mathematics owes its most brilliant successes to precisely that determination which the understanding rejects.

i. Georg Friedrich Hegel, Wissenschaft der Logik I, edited by Eva Moldenhauer and Karl Markus Michel (Suhrkamp, Frankfurt am Main, 1979), 11011; G. W. F. Hegel, The Science of Logic, translated by George di Giovanni (Cambridge, Cambridge UP, 2010), 60. 
Additional Examples A brief list of other places in Goethe's poetry where the Ach functions as a poetic means to enact a philosophical principle would include the penultimate stanza of "Seefahrt" (1776; Sea journey), where the fourfold Ach's of the friends on shore denote the sense of distance - "Ach, warum ist er nicht hiergeblieben!" (FA 1.1:208; Ach, why did he not stay here!") — that is linked to the impending danger on the open seas - "Ach, der Sturm! Verschlagen weg vom Glücke / Soll der Gute so zu Grunde gehen? / Ach er sollte! ach er könnte! Götter!" (FA 1.1:208; Ach, the storm! Swept away from fortune, should the good man thus perish? Ach, should he, ach, he could! Gods!). This series maximizes the feelings of those on the distant shore, as well as the distance between them and the lyrical sailor and the distance between the sailor and the violent world. Interestingly, another deep 'ch-sound' follows and binds this disrupted world back together again, the conceptually and poetically related doch: "Doch er stehet männlich an dem Steuer" (FA 1.1:208; And yet he stands, manly, at the wheel).

A list of further examples would include "Künstlers Morgenlied" (1776; Artist's morning song; FA 1.1:199-201) —three Ach's; "Das Veilchen" (1775; The Violet; FA 1.1:660)_five Ach's (and one "in Acht"); "Neue Liebe, neues Leben" (1775; New love, new life" FA 1:167)—three Ach's); "An Belinden" (1775; To Belinde; FA 1.1:166) —one Ach; "Bleibe, bleibe bei mir" (1775; Stay, oh stay with me; FA 1.1:175)—two Ach's; "Warum gabst du uns die tiefen Blicke" (1776; "Why did you grant us the profound gazes"; FA 1.1:229-231)—two Ach's. In the early Weimar poem, "Dem Schicksal" (1776; To Fate; FA 1.1:249), and its later reworking as "Einschränkung" (1789; The Constraint; FA1. 1:305), the Ach seems to catch a middle space between the recognition that we are carried along and, in a positive sense, limited by the force of fate and nature.

stasis as the informing principle of the self-enclosed yet unfolding movement of life. The poem opens with the desire to pause the fleeting movement of change: "Hielte diesen frühen Segen, / Ach, nur eine Stunde fest!" (FA 1.2:78; If just one hour, Ach, could hold fast to this early blessedness!). The need to draw a breath in order to expel it with the $A c h$ creates, as in an infinitesimal caesura, the desired instant of motionlessness (which, as Galileo and Leibniz said, is just infinitesimal movement). The $A c h$ thus enacts materiality in the declamation of the line, not as the longed-for "hour" of holding fast to what is transitory but as an experience of the paradoxical point of inflection in the process of becoming, or a place between the point when a being stops being what it was and is something other.

This principle of becoming has a long history, and Goethe echoes the pre-Socratic Heraclitus in the second stanza:

Gleich mit jedem Regengusse Ändert sich dein holdes Tal, Ach, und in demselben Flusse Schwimmst du nicht zum zweitenmal. (FA 1.2:78)

As with every downpour your fair valley changes, Ach, and you cannot swim in the same river twice.
The pause introduced by the $A c h$ at the beginning of the line ironically interrupts the flow of its sentiment, which bemoans the incessant flow of being. The interjection thus embodies the very principle of the unity and difference of form and content expressed at the end of the poem:

\author{
Danke, daß die Gunst der Musen \\ Unvergängliches verheißt, \\ Den Gehalt in deinem Busen \\ Und die Form in deinem Geist. (FA 1.2:79)
}

Thanks, that the favor of the Muses promises what will not pass, the content in your breast and the form in your spirit.

Only in this case we see as well that the spirit finds its material expression in the breath of the Ach.

\section{Conclusion: The Materiality of Spirit}

As the interjection Ach plays out throughout Goethe's poetry and Faust, it offers a lyrical instantiation of certain fundamental concepts of Goethean thinking. Indeed, out of this poetic technique of introducing a breathed caesura, a principle emerges that underlies later, more explicitly philosophi- 
cal formulations. At the most concrete level, by giving sound to breath, $A c h$ enacts the materiality of spirit, or the dialectical intertwining of the two. Goethe would express this in the "Erläuterung zu dem aphoristischen Aufsatz 'Die Natur'" (1828; Commentary on the Aphoristic Essay, 'Nature'), where he presents the two driving forces (Triebräder) of nature, Polarität und Steigerung (polarity and intensification): "Weil aber die Materie nie ohne Geist, der Geist nie ohne Materie existiert und wirksam sein kann, so vermag auch die Materie sich zu steigern, so wie sichs der Geist nicht nehmen läßt, anzuziehen und abzustoßen; wie derjenige nur allein zu denken vermag, der genugsam getrennt hat, um zu verbinden, genugsam verbunden hat, um wieder trennen $\mathrm{zu}$ mögen" (FA 1.25:81-82; Because matter never exists without spirit, nor can spirit exist and produce effects without matter, matter is capable of intensification just as spirit cannot but attract and repel; so too thinking is only possible by separating enough to unite [again], and uniting enough to separate again.). Furthermore, as the last part of that explanation demonstrates, a second principle enacted by the $A c h$ is the caesura or hiatus, often placed as the opening, or in the middle of a line of verse, or as an enjambement between lines. This caesura performs the simultaneity of separation and unity, clearest in the famous: "Zwei Seelen wohnen, ach! in meiner Brust" (FA 1.7:57.1112; Two souls dwell, ach, in my breast). At the beginning of a line or poem, it marks the creative, even cosmic, fragmenting into being and individuation-ein schmerzliches Ach (a painful Ach) that rhymes with brach (break) - acting at the same time as the precondition of Wiederfinden (reunion). And finally, in the fleeting moment that it takes to produce the guttural expletive, the interjection performs the dual movements of Systole and Diastole, Einatmen and Ausatmen just by declaiming a line of verse. Ach captures within the unfolding of a line of verse an ontology of natura naturans as living breath. For this reason, it is a central part of Goethe's philosophical lexicon. "Habe nun, ach! Philosophie ..." The philosophy of $A c h$ indeed begins with the same sense of wonder and amazement-but also profound disturbance in the self-that, since Plato and Aristotle, has marked the beginning of all philosophical journeys.

John H. Smith University of California, Irvine 


\section{Notes}

${ }^{1}$ See the entry "Ach" in the Goethe Wörterbuch, ed. Berlin-Brandenburgische Akademie der Wissenschaften, Deutsche Akademie der Wissenschaften zu Berlin, Akademie der Wissenschaften in Göttingen, and the Heidelberger Akademie der Wissenschaften (Stuttgart: Kohlhammer, 1978), columns 237-40.

${ }^{2}$ Works by Goethe are cited according to the Frankfurt edition: Johann Wolfgang von Goethe, Sämtliche Werke. Briefe, Tagebücher und Gespräche, ed. Hendrik Birus, Dieter Borchmeyer, Karl Eibl, et al., 40 vols. (Frankfurt am Main, Deutscher Klassiker Verlag, 1987-2013). Further references will be cited parenthetically as (FA section.volume:page numbers; or FA section.volume:page.line numbers for Faust).

${ }^{3}$ Georg Friedrich Wilhelm Hegel, Phenomenology of Spirit, translated by A. V. Miller (Oxford, Oxford UP, 1977), §16; G. W. F. Hegel, Werke in zwanzig Bänden [Phänomenologie des Geistes], edited by Eva Moldenhauer and Karl Markus Michel, 20 vols. (Frankfurt am Main: Suhrkamp, 1970), 3:22.

${ }^{4}$ Alan Libert, 'Interjections,' Oxford Bibliographies. Last updated Jan. 19, 2019

${ }^{5}$ On the importance of "Gang"-course, walking, proceedingsee Helmut J. Schneider, “' $O$ dass kein Flügel mich vom Boden hebt:' Gang und Blick als Figuren der Überschreitung in Goethes Dichtug (Werthers Leiden, Hermann und Dorothea, Wahlverwandtschaften, Faust)," Goethe Yearbook 27 (2020): 3-30.

${ }^{6}$ Friedrich Kittler, Aufschreibesysteme 1800/1900 (Munich: Wilhelm Fink, 1995), 11.

${ }^{7}$ Martin Heidegger, "Hegels Begriff der Erfahrung," in Holzwege (Tübingen, Max Niemeyer, 1986), 139.

${ }^{8}$ Translations from Faust from Johann von Goethe, Faust with the Urfaust, translated by John R. Williams (Hertfordshire, Wordsworth Editions, 2007), 38.

${ }^{9}$ Another place where Ach appears as substantive can be found in the 1782 poem commemorating the death of the Weimar court's theater director, Johann Martin Mieding ("Auf Miedings Tod;" FA 1.1:362-68). The Ach there marks the point of his passing, but in the form of an "echo" that implies a fullness in the emptiness: "What? Mieding is dead? The empty house resounds to the rafters, and as an echo returns an Ach!" (FA 1.1:363; Wie? Mieding tot? erschallt bis unters Dach/Das hohle Haus, vom Echo kehrt ein Ach!)

${ }^{10}$ Hans Blumenberg, "Aufblick auf eine Theorie der Unbegrifflichkeit," in Schiffbruch mit Zuschauer: Paradigma einer Daseinsmetapher (Stuttgart: Suhrkamp, 1979), 77-93.

${ }^{11}$ This interpretation of "Ganymed" is explored in greater detail in the Goethe Lexicon of Philosophical Concepts entry on Begriff (concept) by Clark Muenzer.

${ }^{12}$ It is tempting to hear in the more famous sister poem, "Ein Gleiches" (A Similar One; FA 1.2:65) a subtle Ach in the barely perceptible "Hauch" (breath) which is there in the treetops, although hardly (kaum) felt. The materiality of breath is thus connected in rhyme to the final "auch," which binds the peacefulness of nature to the longed-for rest of the lyrical subject.

\section{Related Entries in the GLPC}

Atmen (breathe), Begriff (concept), Distichon (distich), Form (form), Geist (spirit), Kraft (force), Rhythmus (rhythm), Materie (material), Symbol (symbol), Urphänomen (primal phenomenon), Diastole und Systole (diastole and systole), Phänomen (phenomenon), Polarität und Steigerung (polarity and intensification), Leiden (suffereing), Schmerz (pain)

\section{Works Cited and Further Reading}

Croce, Benedetto. Aesthetic as Science of Expression and General Linguistic. Translated by Douglas Ainslie. London: Macmillan and Co., 1922

Du Bois, W. E. B. The Souls of Black Folk. Project Gutenberg. Release Date: January 29, 2008 [EBook \#408]. Last updated: November 12, 2019. https://www. gutenberg.org/files/408/408-h/408-h.htm. Last accessed 23 January 2021.

Goethe, Johann Wolfgang von. Sämtliche Werke. Briefe, Tagebücher und Gespräche, ed. Hendrik Birus, Dieter Borchmeyer, Karl Eibl, et al., 40 vols. Frankfurt am Main: Deutscher Klassiker Verlag, 1987-2013.

Goethe, Johann Wolfgang von. Faust with the Urfaust, translated by John R. Williams. Hertfordshire: Wordsworth Editions, 2007.

Hegel, Georg Friedrich Wilhelm. Phenomenology of Spirit, translated by A. V. Miller. Oxford: Oxford UP, 1977.

Hegel, Georg Friedrich Wilhelm. Wissenschaft der Logik I. Edited by Eva Moldenhauer and Karl Markus Michel. Suhrkamp: Frankfurt am Main, 1979.

Heidegger, Martin. "Hegels Begriff der Erfahrung." In Holzwege, 115-208. Tübingen: Max Niemeyer, 1986.

Kittler, Friedrich. Aufschreibesysteme 1800/1900. Munich: Wilhelm Fink, 1995.

Schneider, Helmut J. " $\mathrm{O}$ dass kein Flügel mich vom Boden hebt:' Gang und Blick als Figuren der Überschreitung in Goethes Dichtug (Werthers Leiden, Hermann und Dorothea, Wahlverwandtschaften, Faust)." Goethe Yearbook 27 (2020): 3-30. 